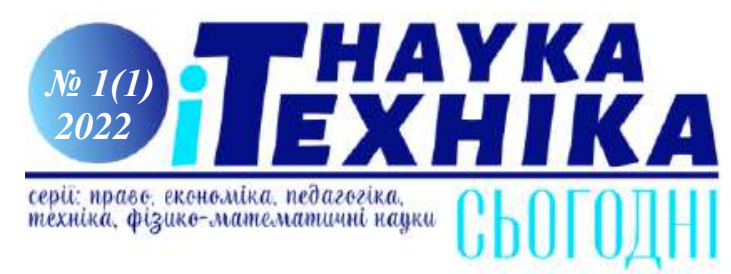

УДК 373.5.016:004

https://doi.org/10.52058/2786-6025-2022-1(1)-73-81

\begin{tabular}{llrlrr} 
Семко Лариса & \multicolumn{1}{c}{ Петрівна } & науковий & \multicolumn{2}{c}{ співробітник відділу } \\
математичної & та & інформатичної & освіти, & Інститут & педагогіки \\
НАПН України, & вул. Січових & Стрільців, & 52Д, м. Київ, 04053, \\
https://orcid.org/0000-0002-7581-3378 & & &
\end{tabular}

\title{
ОСОБЛИВОСТІ ПРИКЛАДНОЇ СПРЯМОВАНОСТІ НАВЧАННЯ ІНФОРМАТИКИ В ШКОЛІ
}

Анотація. Стаття присвячена розгляду особливостей прикладного спрямування у вивченні інформатики в школі та проблемі реалізації прикладного аспекту, який формує в учнів розуміння інформатики, як метод пізнання та перетворення оточуючого світу. Інформатика - прикладна наука, яка має необмежені сфери застосування в сучасному світі: в науці, економіці, техніці, виробництві, освіті. Курс інформатики закликаний внести значний вклад до трудової та політехнічної підготовки учнів. Таке широке використання інформатики в різних сферах життя людини підкреслює важливість вивчення в школі саме прикладних аспектів цієї науки. Суспільству потрібна компетентна, творча особистість, яка здатна брати активну участь у розвитку сучасного виробництва, економіки, науки та культури. Це ставить перед сучасною школою нові завдання вдосконалення освіти і підготовки учнів до практичної діяльності. Одним з напрямків модернізації сучасної інформаційної освіти $\epsilon$ посилення прикладної спрямованості шкільного курсу інформатики, тобто здійснення зв'язку його змісту і методики навчання з практикою. Актуальність посилення прикладної спрямованості шкільного курсу інформатики визначається необхідністю: соціальної затребуваності молодого покоління, здатного застосовувати засоби інформатики та інформаційних технологій; розробки концепції прикладної спрямованості шкільного курсу інформатики та шляхів iї реалізації на різних етапах навчання інформатиці; розкриття i використання дидактичного потенціалу прикладної спрямованості шкільного курсу інформатики; розробки принципів відбору, типізації практичного матеріалу, цікавого з прикладної точки зору, а також розробки і модернізації методики рішення і використання прикладних задач. Акцентується увага на те, що розкриття прикладних аспектів з інформатики та їх використання в процесі навчання складає основний зміст прикладної спрямованості шкільного курсу інформатики. Зазначаються основні етапи та шляхи реалізації навчання прикладної спрямованості шкільного курсу інформатики. У контексті аналізованої проблеми заслуговує на увагу розгляд у статті концепції 
прикладної спрямованості навчання інформатики у школі i шляхи іï реалізації на різних етапах навчання. Прикладна спрямованість курсу інформатики розглядається 3 точки зору двох найважливіших взаємопов'язаних функцій: світоглядної і соціально-педагогічної.

Ключові слова: інформатика, прикладний аспект, інформаційні технології, прикладна спрямованість, концепція.

Semko Larisa Petrovna is a researcher at the Department of Mathematical and Informational Education at the Institute of Pedagogy of the Academy of Pedagogical Sciences of Ukraine, Sichovykh Striltsiv St., 52D, Kyiv, 04053, https://orcid.org/0000-0002-7581-3378

\section{FEATURES OF THE APPLIED DIRECTION OF TEACHING INFORMATICS AT SCHOOL}

Abstract. The article is devoted to the study of specific features of the applied direction in the learning of informatics at school and to the problem of realization of the applied aspect that forms the comprehension of informatics by pupils as a method of cognition and transformation of the surrounding world. Informatics is an applied science that has unbounded spheres of its application in the contemporary world: in science, economy, technique, production, and education. The course of informatics should make a significant contribution to the labor and polytechnical trainings of pupils. Such broad use of informatics in various spheres of the life of a person testifies to the importance of the study of namely the applied aspects of this science at school. The society needs competent creative persons who can take participation in the development of the modern production, economy, science, and culture. This sets new tasks for school that are aimed at the improvement of the education and preparation of pupils to the practical activity. One of the trensa in a modernization of the modern informational education is an enhancement of the applied orientation of the school course of informatics, i.e., the implementation of the connection of its content and the learning methodology with practice. The urgency of a strengthening of the applied orientation of the school course of informatics is determined by the social request for the young generation able to use the tools of informatics and the information technologies. Thus, it is necessary to develop the conception of applied direction of the school course of informatics, to search for the ways to its realization on various stages of the learning of informatics, to clarify and to use the didactic potential of the applied orientation of the school course of informatics, to establish the principles of the selection and typification of a practical material that is of interest from the applied viewpoint, and to develop and to modify the methods of solution and usage of applied problems. Attention is paid to that the clarification of applied aspects of informatics and their use in the process of learning compose the main 


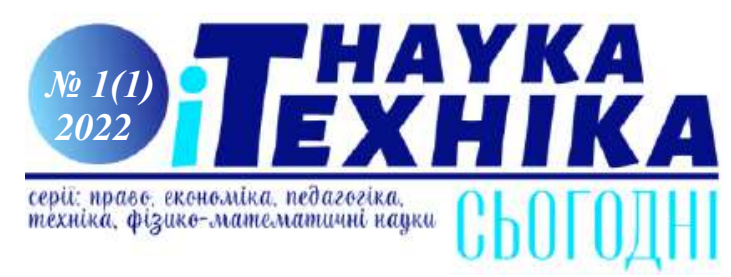

contant of the applied orientation of the school course of informatics. The main stages and ways to a realization of the applied direction of the school course of informatics are indicated. The applied trend of the course of informatics is considered from the viewpoint of two highly important interconnected functions: the world-outlook and social pedagogical ones.

Keywords: informatics, applied aspect, information technology, applied focus, concept.

Постановка проблеми. Сучасні потреби розвитку України вимагають переходу на нову, більш гнучку, ніж існуюча, стратегію інформатичної освіти. Особистісна спрямованість освіти є однією з основних тенденцій розвитку сучасної школи.

Основною метою освітньої галузі “Інформатика" $є$ сформувати знання, уміння і навички, необхідні дня раціонального використання засобів сучасних інформаційно-комунікаційних технологій при розв'язуванні задач, пов'язаних 3 опрацюванням інформації, ऑiі пошуком, систематизацією, зберіганням, поданням, передаванням, ознайомити учнів із роллю нових інформаційнокомунікаційних технологій у сучасному виробництві, науці, повсякденній практиці, з перспективами розвитку комп'ютерної техніки, започаткувати основи інформаційної культури учнів.

Нові поняття і методи, що вивчаються в курсі інформатики, істотно розширюють традиційні межі шкільного інструментарію, формують нові прикладні знання, вміння i навички, які допомагають учням розуміти фундаментальні методи сучасної науки і їх застосування на практиці.

Інформатика - прикладна наука, яка має необмежені сфери застосування в сучасному світі: в науці, економіці, техніці, виробництві, освіті. Курс інформатики має внести значний вклад до трудової та політехнічної підготовки учнів. Таке широке використання інформатики в різних сферах життя людини підкреслює важливість вивчення в школі саме прикладних аспектів цієї науки.

Аналіз останніх досліджень і публікацій. Потреби суспільства визначили соціальне замовлення системі освіти на підготовку фахівців які б володіли на високому рівні знаннями щодо застосування сучасних інформаційнокомунікаційних технологій в процесі розв'язування фахових завдань. А це неможливо без оволодіння знаннями з інформатики та її прикладних аспектів.

Упродовж 35 років в Україні створюється методична система навчання інформатики, яка висвітлена у працях В. Бикова, Н. Балик, А. Верланя, А Гуржія, М. Жалдака, В. Клочка, О. Кузнєцова, Ю. Машбиця, В. Монахова, Н. Морзе, С. Ракова, І. Роберт, 3. Сейдаметової, Ю. Рамського, Ю. Триуса та інших дослідників.

Питанням змісту інформатики займались Л. Білоусова, Я. Глинський, В. Ряжська, Ю. Дорошенко, М. Жалдак, Н. Морзе, І. Сальникова, 
Є. Шестопалов, О. Співаковський. Враховуючи теоретичну значущість і практичну важливість аналізованого питання і з огляду на недостатню його проробку, відсутність наукової аргументації і теоретичного обгрунтування дидактичних та методичних засад методики реалізації прикладної спрямованості навчання інформатики в школі, це питання залишається відкритим.

Крім того, з'являються нові засоби інформаційно-комунікаційних технологій, нове прикладне програмне забезпечення, практика реалізації методичної системи навчання інформатики постійно розвивається. Підкреслюючи значний внесок перерахованих вище авторів, зауважимо, що й багато науковців, учителів, методистів брали участь у дослідженні й обговоренні методичних підходів до навчання прикладних аспектів на уроках інформатики.

Метою статті є розгляд особливостей прикладної спрямованості навчання інформатики в школі. Сьогодні методична система навчання інформатики в старшій школі динамічно змінюється, прагнучи забезпечити максимальне досягнення учнями особистісних, предметних i метапредметних освітніх результатів нової концепції Державного стандарту базової і повної загальної середньої освіти. Постійний пошук найбільш вдалої методики в останні роки тісно пов'язаний 3 розвитком засобів інформаційних технологій, які, за результатами дидактичних i психолого-педагогічних досліджень мають найбільший потенціал.

Для розв'язання поставленої мети використовувалися такі методи дослідження: теоретичний аналіз психолого-педагогічної, наукової і науковометодичної літератури; аналіз матеріалів науково-методичних конференцій 3 комп'ютерних технологій; аналіз програм, навчальних посібників, підручників і методичних рекомендацій; аналіз навчального процесу у школі; педагогічні спостереження, бесіди з учителями і методистами ЗОШ тощо.

Виклад основного матеріалу. Науково-технічна революція у всіх областях людської діяльності висуває нові вимоги до знань, технічної культури, загального і прикладного характеру освіти. Суспільству потрібна компетентна, творча особистість, яка здатна брати активну участь у розвитку сучасного виробництва, економіки, науки та культури. Це ставить перед сучасною школою нові завдання вдосконалення освіти і підготовки учнів до практичної діяльності. Одним з напрямків модернізації сучасної інформаційної освіти $€$ посилення прикладної спрямованості шкільного курсу інформатики, тобто здійснення зв'язку його змісту і методики навчання з практикою [1].

Проблема прикладної спрямованості навчання інформатики не нова i на всіх етапах іiі становлення та розвитку була пов'язана з безліччю питань. Дана проблема динамічна за своїм змістом в силу постійного прогресу IКT, розширення сфери людської діяльності. Складність в цьому процесі полягає в 


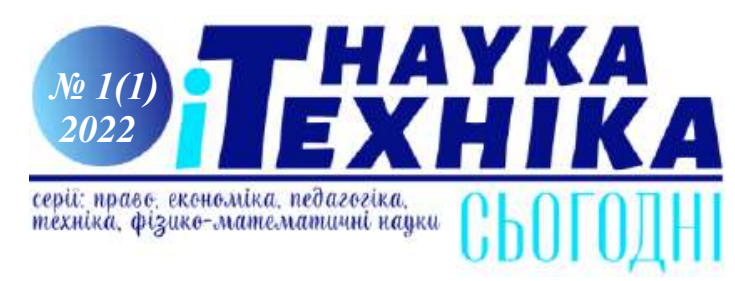

тому, що передбачити всі аспекти застосування інформатики в майбутньої діяльності учнів практично неможливо, а тим більше складно розглянути всі ці питання в школі.

Однак, що може зробити вчитель інформатики, так це сформувати логічну культуру мислення, в тому числі i через рішення прикладних задач. Інформатизація сучасного суспільства ставить перед загальноосвітньою школою проблему виховання в учнів здібностей самостійно i творчо використовувати засоби інформаційних технологій у вирішенні навчальних, а надалі й професійних завдань. Також практика навчання інформатики в школі дозволяє стверджувати, що існує проблемне завдання, яке відображає суперечність між переважаючим прикладним аспектом науки інформатики та недостатнім відображенням цього аспекту в реальній практиці навчання інформатики. Здавалося б, будь-який матеріал курсу інформатики має достатній спектр додатків, однак на практиці виявляється, що більшість учнів не мають уявлення про те, навіщо вивчається цей матеріал, де він буде застосовуватися, $\mathrm{i}$ що він може дати для вирішення конкретних життєво важливих практичних завдань.

Розкриття прикладних аспектів змісту курсу інформатики та їх використання в процесі навчання складає основний зміст прикладної спрямованості під час вивчення інформатики в школі. Загалом можна сказати, що прикладна спрямованість курсу інформатики - здійснення змістового та методичного зв'язку курсу з практикою життєдіяльності сучасної людини в інформаційному суспільстві.

Отже, актуальність посилення прикладної спрямованості курсу інформатики в школі визначається необхідністю [2]:

$\checkmark \quad$ соціальної затребуваності молодого покоління, здатного застосовувати засоби інформатики та інформаційних технологій (IT);

$\checkmark \quad$ розробки концепції прикладної спрямованості шкільного курсу інформатики та шляхів їі реалізації на різних етапах навчання інформатики;

$\checkmark \quad$ розкриття i використання дидактичного потенціалу прикладної спрямованості шкільного курсу інформатики;

$\checkmark \quad$ розробки принципів відбору, типізації практичного матеріалу, цікавого з прикладної точки зору, а також розробки і модернізації методики розв'язання і використання прикладних задач.

На нашу думку, посилення прикладної спрямованості курсу інформатики в школі має бути одним 3 основних моментів модернізації даного курсу. Зазначимо основні з них [3]:

1. В наш інформаційний час необхідність посилення прикладної спрямованості курсу інформатики в школі обумовлена соціальною затребуваністю у молодого покоління. Сьогодні інформатика проникає в усі сфери людської діяльності, тому виникає необхідність кваліфікованої 
підготовки людей різних професій в галузі застосування засобів інформатики та обчислювальної техніки.

2. Прикладна спрямованість шкільного курсу інформатики, iii основні ідеї можуть об'єднати наявні теорії навчання інформатики, розширити і збагатити ці теорії новим, цікавим 3 прикладної точки зору матеріалом. При цьому прикладна спрямованість, що забезпечує змістовий i методичний зв'язок навчання 3 життям, має нерозкритий потенціал. А також i недостатньо використовується дидактичний потенціал для вирішення психолого-педагогічних задач навчання інформатики (активізація мотивації, пізнавального інтересу, розвитку нахилів та здібностей учнів, індивідуалізації та особистісної орієнтації навчання, допрофесійної підготовки учнів, зокрема в галузі використання засобів інформаційних технологій і т.д.). Посилення прикладної спрямованості курсу інформатики дозволяє активізувати, поглибити, збагатити i розширити всі аспекти навчання інформатики (програмістський і світоглядний).

3. Велика роль завдань у вирішенні проблем прикладної спрямованості курсу інформатики в школі очевидна. Особливо відзначимо, що дидактичний потенціал прикладної спрямованості курсу інформатики може слугувати основою наведення порядку в типології цих завдань взагалі i в типології прикладних задач зокрема. Поки ж завдання 3 прикладним змістом відбираються випадковим чином, прикладний аспект наявних завдань не розкривається i не використовується, діяльність учнів із самостійного складання прикладних задач і вибору критеріїв їх класифікації не активізується.

Все вищесказане підтверджує необхідність дослідження питань прикладної спрямованості шкільного курсу інформатики, яка визначається відсутністю системного загального погляду на курс інформатики як прикладної навчальної дисципліни, нерозробленістю змістового та методичного аспектів реалізації прикладної спрямованості шкільного курсу інформатики, практичною необхідністю розвитку в учнів здатності застосовувати, постійно поповнювати і вдосконалювати запас наявних у них на озброєнні знань і навичок з інформатики.

У контексті аналізованої проблеми заслуговує на увагу розробка концепції прикладної спрямованості навчання інформатики у школі і шляхи iii реалізації на різних етапах навчання. Ця концепція включає в себе [4]:

$\checkmark$ цілі, завдання та функції прикладної спрямованості шкільного курсу інформатики;

$\checkmark$ дидактичне, змістовно-методичне та програмно-технічне забезпечення прикладної спрямованості шкільного курсу інформатики;

$\checkmark$ принципи прикладної спрямованості шкільного курсу інформатики в умовах безперервної освіти; 


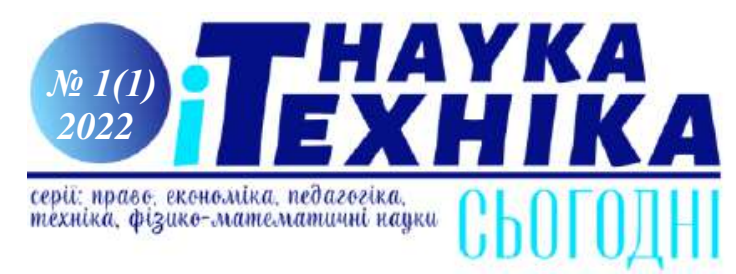

$\checkmark$ рівні прикладної спрямованості шкільного курсу інформатики, які враховують вікові особливості та здібності учнів;

$\checkmark$ вимоги до вчителя інформатики в області його готовності до реалізації прикладної спрямованості шкільного курсу інформатики;

$\checkmark \quad$ шляхи реалізації прикладної спрямованості на різних етапах навчання інформатики.

Розробка концепції прикладної спрямованості шкільного курсу інформатики, на нашу думку, необхідна не тільки для розробки теоретично обгрунтованих i експериментально перевірених принципів реалізації (проекції) понять, цілей, завдань і функцій прикладної спрямованості шкільного курсу інформатики на всіх етапах навчання (пропедевтичний, базовий, профільний), але i в більшій степені для розробки критеріїв виділення (відбору) інваріанта прикладного змісту (знань) шкільного курсу інформатики, інваріанта прикладної навчальної діяльності та системи прикладних задач, що реалізують цю діяльність.

Обмін думками 3 учителями інформатики дали змогу припустити, що розробка концепції прикладної спрямованості шкільного курсу інформатики дозволить впровадити в практику навчання в школі системний підхід щодо здійснення прикладної спрямованості шкільного курсу інформатики.

Це дозволить: вирішити соціальні завдання; об'єднати і збагатити існуючі теорії навчання інформатиці; вирішити психолого-педагогічні завдання курсу інформатики; створити методичну основу збірників задач прикладного змісту.

Дослідження і практичний досвід методистів і вчителів - практиків показує, що суть системного підходу до процесу реалізації прикладної спрямованості курсу інформатики в школі полягає в одночасному розгляді таких питань:

$\checkmark$ прикладна орієнтація вивчення теоретичного матеріалу; виділення і використання прикладних аспектів наявних завдань шкільного курсу інформатики;

$\checkmark$ розробка, типізація, рішення і використання прикладних задач;

$\checkmark$ використання нових прикладних методів і засобів у вивченні теоретичного матеріалу і рішення задач;

$\checkmark$ використання нових форм організації навчання курсу, який орієнтований на посилення прикладної спрямованості курсу інформатики.

Під час навчання інформатики важливо враховувати наступні моменти: вдосконалення змісту (прикладна орієнтація його вивчення); виділення прикладного аспекту наявних завдань шкільного курсу інформатики, рішення прикладних задач; використання засобів інформаційних i комунікаційних технологій, нових методів і форм навчання.

Посилення прикладної спрямованості курсу інформатики, на нашу 
думку, більшою мірою може бути здійснено за рахунок використання нових методів і форм навчання, що використовують можливості обчислювальної техніки, i, головне, за рахунок вирішення прикладних завдань і прикладної орієнтації типових задач.

Зауважимо, що прикладну спрямованість шкільного курсу інформатики можна розглядати з точки зору двох найважливіших взаємопов'язаних, але цілком самостійних функцій, які вона може реалізувати: світоглядної i соціально-педагогічної. Світоглядна функція реалізується при використанні інформатики в інших шкільних навчальних предметах, при вивченні історії виникнення i розвитку понять інформатики, а також при абстрагуванні різних рівнів, знайомстві 3 елементами моделювання реальних процесів, конструюванні алгоритмів, програм і т.п.

Соціально-педагогічна функція прикладної спрямованості шкільного курсу інформатики реалізується під час профорієнтаційної роботи з учнями. Тому вивчення шкільного курсу інформатики повинне містити вирішення практичних завдань 3 різних областей діяльності людини. Важливість використання прикладних задач визначається роллю цих завдань у розвитку пізнавального інтересу учнів, їх творчих можливостей, самостійності, гнучкості розуму, вмінь узагальнювати знання з різних предметів, а також у розвитку інформаційної культури учнів. Кожному 3 нас доводиться вирішувати безліч різних завдань. 3 ними ми постійно стикаємося вдома, на вулиці, в школі і на роботі [5].

Прикладне спрямування курсу інформатики, на нашу думку, дозволить посилити міжпредметні зв’язки «фізика - математика - інформатика», забезпечити підвищення внутрішньої мотивації учнів, інтенсифікувати процеси засвоєння навчального матеріалу.

Висновки. Як показує досвід, реалізація прикладної спрямованості навчання інформатики за рахунок забезпечення єдності теорії і практики дозволяє учням засвоїти i оцінити прикладні можливості інформатики та отримати основні вміння на практиці. Важливість розробки проблеми посилення прикладної спрямованості шкільного курсу інформатики визначається загальними завданнями, що стоять перед сучасними середніми освітніми установами.

Прикладна спрямованість навчання інформатики формує в учнів розуміння інформатики, як методу пізнання та перетворення оточуючого світу. Застосування знань $з$ інформатики до розв'язування задач прикладного змісту сприяють зміцненню мотивації навчання, системності, дієвості, гнучкості знань, стимулють пізнавальні інтереси учнів. Навчання інформатики має велике значення для реалізації потенціалу загальної середньої освіти і змінюється в умовах фундаменталізації змісту освіти, що, у свою чергу, впливає на методичну систему навчання інформатики. 


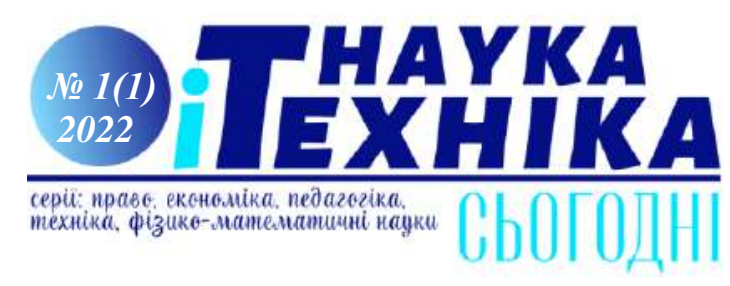

Нині стає все більш зрозуміло, що в курсі інформатики необхідно освоювати не лише часткові аспекти прикладної спрямованості, а й формувати загальні основи взаємодії з інформаційними технологіями, узагальнені методи i засоби.

\section{Jimepamypa:}

1. Семко Л., Самойленко Н. Методичні підходи до вивчення інформатики в основній школі. Наукові записки. Випуск 7. Серія: Проблеми методики фізико-математичної $i$ технологічної освіти. Частина 2. Кіровоград, 2015. С.76-82.

2. Семёнова О.В. Реализация прикладной направленности учебного предмета «Информатика». Интернет-технологии в образовании, Москва. 2018. С. 84-88.

3. Гриншкун В.В., Левченко И.В. Школьная информатика в контексте фундаментализации образования. Вестник Российского университета дружбы народов. Серия: Психология и педагогика. Москва. 2009. С.55-63.

4. Морзе Н.В. Методика навчання інформатики : Навч. пос. 2004. Частина 2. С.287.

5. Семко Л.П., Лапінський В.В. Методичні аспекти вивчення інформатики в ліцеї на рівні стандарту. Наукові записки Випуск 177. Частина I. Серія: Педагогічні науки. Кропивницький. 2019. С. 212-216.

\section{References:}

1. Semko L., Samoilenko N. Metoduchni pidhodu do vuvchennya informatuku v osnovniy shkoli [Methodical approaches to the study of computer science in primary school. Proceedings]. Issue 7. Series: Problems of methods of physical-mathematical and technological education. Part 2. Kirovograd,2015. P.76-82.

2. Semyonova OV Realizaciya Realizaciya prikladnoy napravlennosti uchebnogo predmeta «Informatika» [Implementation of the applied orientation of the educational subject "Informatics". Internet technologies in education]. Moscow.2018.P.84-88.

3. Grinshkun V.V., Levchenko I.V. Shkolnaya informanirka $v$ kontekste fundamentalizacii obrazovaniya [School informatics in the context of the fundamentalization of education]. Bulletin of the Peoples' Friendship University of Russia. Series: Psychology and Pedagogy. Moscow.2009. P.55-63.

4. Morse N.V. Metoduka navchannya informatuku [Technique of Navchannya informatics]: Navch. pos. 2004. Part 2. P.287.

5. Semko LP, Lapinsky VV Metoduchni aspektu vuvchennya informatuku v licei na rivni standartu [Methodical aspects of studying computer science in lyceum at the standard level]. Scientific Notes Issue 177. Part I. Series: Pedagogical Sciences. Kropyvnytskyi.P. 212-216. 